\title{
Lichen flora of Surinsar-Mansar wildlife sanctuary, J\&K
}

\author{
Mukhtar A. Sheikh ${ }^{1}$, Anil K. Raina ${ }^{1 *}$ and D. K. Upreti ${ }^{2}$ \\ ${ }^{1}$ Department of Environmental Sciences, University of Jammu, Jammu-180001, INDIA \\ ${ }^{2}$ Lichenology Lab., National Botanical Research Institute, Lucknow-226001, INDIA \\ *Corresponding author. E-mail: anilkraina@yahoo.com
}

\begin{abstract}
The present study conducted to enumerate the lichens from the so far unexplored Surinsar-Mansar wildlife sanctuary, J\&K, revealed the presence of 30 species belonging to 18 genera from 14 families. The species belonged to different growth forms (21 crustose, 8 foliose and 1 fruticose) and are also growing on various substrata (corticolous17 and saxicolous-13). Mangifera indica hosted the maximum number (12) while Pinus roxburghii did not host any lichen species in this area.
\end{abstract}

Key Words: Lichen flora, Surinsar-Mansar wildlife sanctuary, J\&K.

\section{INTRODUCTION}

Lichens dominate $8 \%$ or more of the earth's terrestrial area (Ahmadjian, 1995). These are amongst the most significant indicators of air pollution and ecosystem health (Richardson 1992; Upreti and Pandev 1994; Wolseley et al. 1994; Upreti, 1995; Sloof, 1995; Mistry, 1998; Vokou et al., 1999). Lichens form important component of biodiversity of any area and have been explored exhaustively from the different region of the country including the Himalaya in the last half of the $20^{\text {th }}$ century. However, the Jammu province of J\&K State, which is also an important segment of the Himalayan belt, has not received much attention except for few reports (Awasthi and Singh,1970; Sheikh et al., 2006 a and $b$ ).

The systematic exploration of the lichen flora has been made from lichenologically unexplored Surinsar-Mansar Wildlife Sanctuary (latitude $32^{\circ} 41^{\prime}$ to $32^{\circ} 49^{\prime} \mathrm{N}$, longitude $74^{\circ} 59^{\prime}$ to $75^{\circ} 59^{\backslash} \mathrm{E}$ and altitude 540- $835 \mathrm{~m}$ above m.s.l with an area of $97.82 \mathrm{sq}$. kms) which has got its name from the twin lakes situated at two corners of this Wildlife sanctuary. The vegetation in this Sanctuary comprises of Northern dry mixed deciduous forest, Himalayan subtropical dry scrub and Himalayan subtropical pine forest. The area is dominated by the different trees like, Acacia catechu, Acacia modesta, Albizzia lebbeck, Bombax ceiba, Cassia fistula, Dalbergia sissoo, Ficus benghalensis, F. palmata Lannea coromandelica, Mallotus philippensis, Mangifera indica, Melia azedarach, Phoenix sylvestris, Phyllanthus emblica, Pinus roxburghii and Toona ciliata, etc. which are supporting the lichen flora.

\section{MATERIALS AND METHODS}

The lichen collections were made from base to head height of the tree trunks and rocks. Along with the lichen collection the details of locality, substratum and altitude were also recorded. The labeled and dried specimens have been lodged in the Lichen Herbarium of National Botanical Research Institute (LWG), Lucknow. The specimens were identified by studying the morphology, anatomy and chemistry. The recent literature of Awasthi (1988, 1991 and 2000), Singh and Upreti (1984), Upreti, (1988), Divakar (2001) and Nayaka (2004) was consulted for identification of most of the lichen taxa. The morphology of the taxa was studied under stereo-zoom binocular microscope. Anatomical details of the thallus and fruiting bodies were studied in free hand sections with water as mounting medium under compound microscope. The colour spot tests were carried out on cortex and medulla with the usual chemical reagents, such as aqueous potassium hydroxide $(\mathrm{K})$, Steiner's stable para-phenylenediamine (PD) and aqueous calcium hypochlorite (C). Thin Layer Chromatography was performed for authentic identification of the lichen substances in solvent system A(Toluene, $180 \mathrm{ml}$ : 1-4 Dioxane, 60ml : Acetic acid,8 ml) following Walker and James (1980).

\section{RESULTS AND DISCUSSION}

The survey of Lichens species growing on different substratum - trees and rocks, in the Surinsar-Mansar Wildlife Sanctuary revealed the presence of 30 species of lichens, belonging to18 genera and 14 families (Table 1).

Diversity of Lichens : The perusal of the table 
revealed that the area is dominated by crustose lichens (21 species) as compared to foliose lichens (8 species). Cladonia corniculata is the only fruticose lichen recorded from the area. On the basis of substratum type 17 species have been observed to be corticolous (growing on the bark of trees) while 13 have been recorded as saxicolous (growing on rocks). Physciaceae and Verrucariaceae with 4 genera \& 6 species each have been observed to be the most dominant families in the Sanctaury. These are followed by Teloschistaceae with 2 genera and 4 species. Similarly, Caloplaca and Pyxine with 3 species each, have been recorded as the dominant genera of the area. Phaeophyscia orbicularis, Hyperphyscia adglutinata, Pyxine subcinerea, Lepraria lobificans, Dermatocarpon miniatum, Dermatocarpon vellereum, Lecanora perplexa, Phylliscum indicum and Endocarpon subrosettum have been observed to be the most common lichens growing in the sanctuary.
Vegetation vs Lichens : The different lichen species growing on different trees in Surinsar-Mansar Wildlife Sanctuary has been depicted in Table 2 . The perusal of the table reveals that the Mangifera indica is hosting the maximum number of lichen species (12) which may be attributed to the texture of bark - smooth and fissured bark. Survey also revealed the presence of seven lichen species on Mallotus philippensis, six on Toona ciliata, 3 each on Albizzia lebbeck and Ficus palmata, and 2 lichen species each on Acacia modesta, Bombax ceiba, Cassia fistula, Dalbergia sissoo, Ficus benghalensis,, Lannea coromandelica, Melia azedarach and Phyllanthus emblica while Phoenix sylvestris has been found to host only one lichen species. Pinus roxburghii , one of the dominant tree of the study area, did not host any lichen species which may be attributed to the exfoliating nature of bark.

Visual observation also revealed that the rocks along the

Table 1. Lichens with their growth forms and substratum from Surinsar-Mansar wildlife sanctuary.

\begin{tabular}{|c|c|c|c|c|}
\hline S. No. & Lichen taxa & Family & $\begin{array}{c}\text { Growth } \\
\text { Form } \\
\end{array}$ & Substratum \\
\hline 1. & Bacidia sp. & Bacidiaceae & $\mathrm{C}$ & Co \\
\hline 2. & Buellia sp. & Physciaceae & $\mathrm{C}$ & Co \\
\hline 3. & Caloplaca malensis (Rasanen) Awasthi & Teloschistaceae & $\mathrm{C}$ & Co \\
\hline 4. & Caloplaca kashmirensis Joshi, Y. \& Upreti & Teloschistaceae & $\mathrm{C}$ & Co \\
\hline 5. & Caloplaca subsolata (Nyl.) Zahlbr. & Teloschistaceae & $\mathrm{C}$ & $\mathrm{S}$ \\
\hline 6. & Candelaria concolor (Dicks.) B. Stein. & Candelariaceae & $\mathrm{F}$ & $\mathrm{Co}$ \\
\hline 7. & Catillaria pulverea (Borrer ) Lettau & Catillariaceae & $\mathrm{C}$ & $\mathrm{Co}$ \\
\hline 8. & Cladonia cartilaginea Müll. Arg. & Cladoniaceae & Fr & $\mathrm{S}$ \\
\hline 9. & Cryptothecia sp. & Arthoniaceae & $\mathrm{C}$ & S \\
\hline 10. & Dermatocarpella squamulosum (Ach.) H.Harada & Verrucariaceae & $\mathrm{C}$ & S \\
\hline 11. & Dermatocarpon miniatum (L.) Mann. & Verrucariaceae & $\mathrm{C}$ & $\mathrm{S}$ \\
\hline 12. & Dermatocarpon vellereum Zschacke. & Verrucariaceae & $\mathrm{F}$ & $\mathrm{S}$ \\
\hline 13. & Endocarpon rosettum A.Singh \& Upteri & Verrucariaceae & $\mathrm{C}$ & $\mathrm{S}$ \\
\hline 14. & Endocarpon subrosettum A.Singh \& Upteri & Verrucariaceae & $\mathrm{C}$ & $\mathrm{S}$ \\
\hline 15. & Hyperphyscia adglutinata (Flörke) Mayrh. \& Poelt & Physciaceae & $\mathrm{F}$ & $\mathrm{Co}$ \\
\hline 16. & Lecanora perplexa Brodo. & Lecanoraceae & $\mathrm{C}$ & $\mathrm{Co}$ \\
\hline 17. & Lecanora sp. & Lecanoraceae & $\mathrm{C}$ & Co \\
\hline 18. & Lepraria lobificans Nyl. & Lichenes imperfecti & $\mathrm{C}$ & $\mathrm{S}$ \\
\hline 19. & Lepraria sp. & Lichenes imperfecti & $\mathrm{C}$ & Co \\
\hline 20. & Parmotrema praesorediosum (Nyl.) Hale & Parmeliaceae & $\mathrm{F}$ & Co \\
\hline 21. & Pertusaria quassiae (Fée) Nyl. & Pertusariaceae & $\mathrm{C}$ & Co \\
\hline 22. & Pertusaria $\mathrm{sp}$ & Pertusariaceae & $\mathrm{C}$ & Co \\
\hline 23. & Phaeophyscia orbicularis (Necker) Moberg. & Physciaceae & $\mathrm{F}$ & Co \\
\hline 24. & Phylliscum indicum Upreti & Lichinaceae & $\mathrm{C}$ & $\mathrm{S}$ \\
\hline 25. & Phylliscum sp. & Lichinaceae & $\mathrm{C}$ & $\mathrm{S}$ \\
\hline 26. & Pyxine cocoes (Sw.) Nyl. & Physciaceae & $\mathrm{F}$ & $\mathrm{Co}$ \\
\hline 27. & Pyxine petricola Nyl. in Crombie & Physciaceae & $\mathrm{F}$ & $\mathrm{Co}$ \\
\hline 28. & Pyxine subcinerea Stirton & Physciaceae & $\mathrm{F}$ & Co \\
\hline 29. & Verrucaria acrotella Ach. & Verrucariaceae & $\mathrm{C}$ & $\mathrm{S}$ \\
\hline 30. & Xanthoria elegans (Link.) Th.Fr. & Teloschistaceae & $\mathrm{C}$ & $\mathrm{S}$ \\
\hline
\end{tabular}

Note: $\mathrm{C}=$ Crustose, $\mathrm{F}=$ Foliose, $\mathrm{Fr}=$ Fruticose, $\mathrm{Co}=$ Corticolous, $\mathrm{S}=$ Saxicolous . 
Table 2. Lichen species growing on different trees in Surinsar-Mansar wildlife sanctuary.

\begin{tabular}{|c|c|c|}
\hline S. No. & Lichen taxa & Tree type \\
\hline 1. & Bacidia sp. & Mallotus, Mangifera \\
\hline 2. & Buellia sp. & Mallotus \\
\hline 3. & Caloplaca malensis (Rasanen) Awasthi & Mallotus, Mangifera, Toona \\
\hline 4. & Caloplaca kashmirensis Joshi, Y. \& Upreti & Mangifera, \\
\hline 5. & Candelaria concolor (Dicks.) B. Stein. & Mangifera, \\
\hline 6. & Catillaria pulverea (Borrer) Lettau & Mangifera, \\
\hline 7. & Hyperphyscia adglutinata (Flörke) Mayrh. \& Poelt & $\begin{array}{l}\text { Acacia modesta, Albizzia, Cassia, Dalbergia, } \\
\text { Ficus benghalensis, F. palmata, Lannea, } \\
\text { Mallotus, Mangifera, , Melia, Phyllanthus, } \\
\text { Toona }\end{array}$ \\
\hline 8. & Lecanora perplexa Brodo. & Mallotus, Mangifera, Toona \\
\hline 9. & Lecanora sp. & Mallotus, Toona \\
\hline 10. & Lepraria sp. & Mallotus Mangifera, \\
\hline 11. & Parmotrema praesorediosum (Nyl.) Hale & Albizzia, \\
\hline 12. & Pertusaria quassiae (Fée) Nyl. & Bombax \\
\hline 13. & Pertusaria sp. & Mangifera \\
\hline 14. & Phaeophyscia orbicularis (Necker) Moberg. & $\begin{array}{l}\text { Acacia modesta, Albizzia, Cassia, Dalbergia, } \\
\text { Ficus benghalensis, F. palmata, Lannea, } \\
\text { Mallotus, Mangifera, , Melia, Phyllanthus } \\
\text { Phoenix, Toona }\end{array}$ \\
\hline 15. & Pyxine cocoes (Sw.) Nyl. & Mangifera, Melia \\
\hline 16. & Pyxine petricola Nyl. in Crombie & Bombax \\
\hline 17. & Pyxine subcinerea Stirton & Ficus palmata, Mangifera, Melia, Toona \\
\hline
\end{tabular}

springs and small streams passing through the sanctuary have more diversity of lichens both qualitatively and quantitatively.

The available enumeration of lichens will act as a baseline record for carrying out future biomonitoring studies in the area.

\section{REFERENCES}

Ahmadjian, V. (1995). Lichens are more important than you think. BioScience, 45. 124.

Awasthi, D.D. (1988). A key to the Macrolichens of India and Nepal. J. Hattori Bot. Lab. 65:207- 303.

Awasthi, D.D. (1991). A key to the Microlichens of India, Nepal and Sri Lanka. Bibliotheca Lichenologica (Suppl.) 40: 1-337.

Awasthi, D.D. (2000). Lichenology in Indian Subcontinent. Publication: Bishen Singh Mahendra Pal Singh., Dehradun

Awasthi, D.D. and Singh, K.P. (1970). A note on lichens from Kashmir. Curr. Sci. 39: 441-442.

Divakar, P.K. (2001). Revisionary studies on the lichen genus Parmelia sensu lato india. Ph.D. Thesis, Lucknow University, India.

Mistry, J. (1998). A preliminary lichen-fire history key for the Cerradoof the Distrito Federal, central Brazil; J. Biogeogr. 25: 443-452.

Nayaka, S. (2004). Revisionary studies on the lichen genus Lecanora sensu lato in India. Ph.D. Thesis, Dr R.M.L Avadh University Faizabad, India.

Richardson ,D. H. S.(1992). Pollution monitoring with lichens, Richmond, England.
Sheikh, M.A., Upreti, D.K. and Raina, A.K. (2006 a). An enumeration of lichens from three districts of Jammu \& Kashmir, India. J. Appl .Biosci., 32(2): 189-191.

Sheikh, M.A., Upreti, D.K. and Raina, A.K. (2006 b). Lichens diversity in Jammu \& Kashmir, India. Geophytology 36(1\&2): 69-85.

Singh, A. and Upreti, D.K. (1984). The lichen genus Endocarpon from India. Candollea, 39:539-548.

Sloof, J. E. (1995). Lichens as quantitative biomonitors for atmospheric trace-element deposition: using transplants. Atmos. Environ., 29: 11-20.

Upreti, D.K. (1988). A new species of lichen genus Phylliscum from India. Curr.sci., 57(16): 906-907.

Upreti, D. K. (1995). Loss of diversity in Indian lichen flora. Environ. Conser. 22:362-363.

Upreti, D. K. and Pandev, V. (1994). Heavy metals of Antarctic lichens: 1. Umbilicaria; Feddes Report. 105: 197-199.

Vokou. D., Pirintsos, S. A and Loppi, S. (1999). Lichens as bioindicators of temporal variation in air quality around Thessaloniki, Northern Greece. Ecol. Res. 14 89-96.

Walker, F.J. and James, P.W. (1980). A revised guide to microchemical techniques for the identification of lichen substances. Bull. Brit. Lichen. Soc. 46:13-29 (Suppl.).

Wolseley, P. A., Moncrieff, C. and Aguirre-Hudson, B.(1994). Lichens as indicators of environmental stability and change in the tropical forests of Thailand. Global Ecol. Biogeogr. Lett. 116-123. 